\title{
An atypical presentation of acute fatty liver of pregnancy
}

O U Onwuagbu, ${ }^{1} \mathrm{MB}$ BCh, Dip Obst (SA); C N Mnyani, ${ }^{1}$ BA, MB ChB, FCOG (SA), PhD; N Ntshwanti, ${ }^{2}$ MB ChB, FC Path (SA) Anat; R Wadee, ${ }^{2} \mathrm{MB}$ BCh, FCPath (SA), MMed (Anat Path)

${ }^{1}$ Department of Obstetrics and Gynaecology, School of Clinical Medicine, Faculty of Health Sciences, University of the Witwatersrand, Johannesburg, South Africa

${ }^{2}$ Department of Anatomical Pathology, School of Pathology, Faculty of Health Sciences, University of the Witwatersrand, Johannesburg, South Africa.

\section{Corresponding author: O U Onwuagbu (otanneze@yahoo.co.uk)}

Acute fatty liver of pregnancy (AFLP) is an uncommon but life-threatening condition unique to pregnancy, affecting $\sim 1$ in 10000 pregnancies, and is the most common cause of liver failure in pregnancy. Here the case is described of a 35 -year-old patient who presented at 21 weeks' gestation complaining of vomiting, epigastric pain and food intolerance. During the course of her hospital stay of 31 days, she developed electrolyte imbalances and derangement in liver functions, with coagulopathy and bicytopenia. While she was being investigated for the cause of the biochemical abnormalities, she developed sepsis and anasarca, with a deterioration of her general condition, and it was decided to eliver the fetus. A diagnosis of AFLP was made on histological evaluation of a liver biopsy performed 3 days prior to delivery.

S Afr J Obstet Gynaecol 2018;24(2):40-42. DOI:10.7196/SAJOG.2018.v24i2.1271

Acute fatty liver of pregnancy (AFLP) is an uncommon but lifethreatening condition unique to pregnancy, affecting $\sim 1$ in 10000 pregnancies, and is the most common cause of liver failure in pregnancy ${ }^{[1]}$ AFLP carries a high maternal mortality rate of up to $75 \%$, and a perinatal mortality rate of up to $85 \%$, but with earlier diagnosis and the institution of timeous definitive management, i.e. delivery, these rates are reduced to $18 \%$ and $23 \%$, respectively. ${ }^{[2]}$ The condition usually presents in the third trimester of pregnancy, between 30 and 38 weeks' gestation, with a recurrence rate of $20 \%$ in subsequent pregnancies. ${ }^{[3]}$ The diagnosis is based on the patient having at least six of the Swansea criteria, a combination of clinical and laboratory features (Table 1)..$^{[3,4]}$

The key to management of AFLP is timeous diagnosis and prompt termination of pregnancy or delivery, requiring a multidisciplinary approach in an intensive care unit. ${ }^{[2]}$ Clinical recovery usually ensues in 3 - 4 days postpartum, but abnormalities in laboratory parameters may persist for much longer. ${ }^{[5]}$

Table 1. Swansea diagnostic criteria ${ }^{[3]}$

\begin{tabular}{lll}
\hline Laboratory & Clinical & Other \\
\hline Bilirubin $>14 \mu \mathrm{mol} / \mathrm{L}$ & Vomiting & $\begin{array}{l}\text { Ultrasound showing } \\
\text { ascites/ bright liver }\end{array}$ \\
Hypoglycaemia $<4 \mathrm{mmol} / \mathrm{L}$ & Abdominal pain & $\begin{array}{l}\text { Histology showing } \\
\text { microvesicular } \\
\text { steatosis }\end{array}$ \\
Uric acid $>340 \mu \mathrm{mol} / \mathrm{L}$ & $\begin{array}{l}\text { Polydipsia and } \\
\text { polyuria }\end{array}$ & \\
Leukocytosis $>11 \times 10^{6} / \mathrm{L}$ & Encephalopathy \\
AST/ALT $>42 \mathrm{IU} / \mathrm{L}$ & \\
Ammonia $>47 \mu \mathrm{mol} / \mathrm{L}$ & \\
Creatinine $>150 \mu \mathrm{mol} / \mathrm{L}$ & \\
Coagulopathy, PT $>14 \mathrm{~s}$ & \\
AST= aspartate transaminase; ALT= alanine transaminase; PT= prothrombin time.
\end{tabular}

\section{Case report}

A 35-year-old nulliparous patient, with two previous first-trimester miscarriages, presented at 21 weeks' gestation with a history of vomiting, epigastric pain and food intolerance since the onset of the pregnancy. She was noted to be dehydrated, with a blood pressure of $99 / 50 \mathrm{mmHg}$ and a heart rate of 80 beats per minute. Her glucose level was $5.6 \mathrm{mmol} / \mathrm{L}$, and she had ketonuria. Biochemistry results showed hypokalaemia of $1.9 \mathrm{mmol} / \mathrm{L}$ and hypocalcaemia of $1.82 \mathrm{mmol} / \mathrm{L}$. She was HIV-negative. An ultrasound showed a single intrauterine pregnancy, with a gestational age of 22 weeks and 4 days.

She was admitted with a diagnosis of hyperemesis gravidarum and treated with antiemetics, intravenous fluids and electrolyte replacement. Repeat liver function tests performed on the fifth day of admission revealed hypoproteinaemia with a total protein of $45 \mathrm{~g} / \mathrm{L}$ and an albumin of $22 \mathrm{~g} / \mathrm{L}$. In addition, her liver function test showed the following: hyperbilirubinaemia of $33 \mu \mathrm{mol} / \mathrm{L}$, aspartate transaminase of $389 \mathrm{IU} / \mathrm{L}$, alanine transaminase of $1111 \mathrm{IU} / \mathrm{L}$ and serum creatinine level of $56 \mu \mathrm{mol} / \mathrm{L}$. The viral hepatitis screen and screening for autoimmune conditions were negative (Table 2). An abdominal ultrasound showed a mildly echogenic liver, which is a feature that is not specific to AFLP, with no other pathology detected.

It was decided to manage the patient conservatively while investigating the cause of the electrolyte imbalance. There was a spontaneous improvement in her liver function tests (Table 2) on day 7 of admission, while the patient was still pregnant. On day 12 of admission, there was a rebound worsening of the liver function tests, which was complicated by anaemia, thrombocytopenia and coagulopathy, with a haemoglobin of $7.0 \mathrm{~g} / \mathrm{dL}$, a platelet count of $113 \times 10^{9} / \mathrm{L}$ and an international normalised ratio of 3.72. Although the patient had been normotensive throughout her admission, a differential diagnosis of HELLP syndrome - haemolysis, elevated liver enzymes and low platelets - was made. She then had a blood 
transfusion and also received fresh frozen plasma. This was followed by an improvement in liver functions and electrolytes, and a return to normal coagulation within 24 hours.

On day 17 of the patient's admission, a liver biopsy was undertaken to determine the cause of her liver dysfunction. While awaiting the liver biopsy results, she developed signs of sepsis, and blood cultures grew Gram-negative bacilli, Serratia marcescens, which was sensitive to ertapenem. She also developed anasarca, and as a result of her deteriorating condition, a decision was taken to deliver the fetus. She delivered at $25 \mathrm{w} 3 \mathrm{~d}$ gestation, and a live female was born, with a birth weight of $720 \mathrm{~g}$. Unfortunately, the neonate died 4 days postpartum from complications of prematurity.

Histopathological evaluation of the core liver biopsy demonstrated ballooning and feathery degeneration of hepatocytes. Microvesicular steatosis was noted in approximately $80 \%$ of the liver core. There was evidence of both intra- and extrahepatic cholestasis (Fig. 1). A final diagnosis of AFLP was made.

Following delivery, there was a marked clinical improvement in the patient's condition, as well as improvement in her liver function tests. She was discharged after 30 days post admission, and was to follow up at the medical gastrointestinal outpatients' department.

\section{Discussion}

Our patient had an atypical presentation of AFLP. She presented at an early gestation of 22 weeks, whereas the average gestational age of presentation is in the third trimester, at a median gestational age of 36 weeks. It has also been reported in the puerperium, being diagnosed at an average of 4 days into the postpartum period. ${ }^{\left[{ }^{[6]}\right.}$ She did not meet the required Swansea criteria for AFLP, as the most she had at any one time were five criteria, instead of the minimum of six. Her glucose levels and renal function remained normal throughout her hospital stay, and she was not encephalopathic at any point. There was also spontaneous improvement in her liver function half way through her admission, but it later deteriorated. However, the presence of microvesicular steatosis on core liver biopsy eventually confirmed the diagnosis of AFLP. The source of septicaemia in our patient could not be determined, as urine and sputa cultures did not grow the Gram-negative bacilli that were found on the blood culture. Septicaemia has been documented as one of the morbidities associated with AFLP. ${ }^{[6]}$

The Swansea criteria are a group of clinical and laboratory features gathered and used in the absence of any other explanation

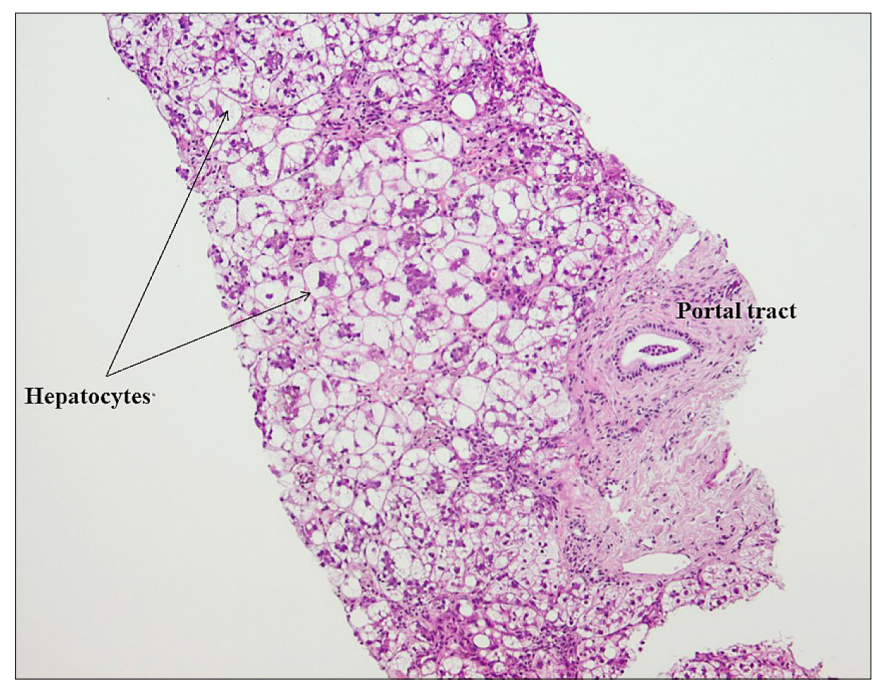

Fig. 1. Liver core biopsy showing a portal tract on the right. The hepatocytes show extensive feathery degeneration and ballooning (arrows). $2 \mu \mathrm{m}$ section, original magnification $\times 100$.

Table 2. Biochemistry and haematology results

\begin{tabular}{|c|c|c|c|c|c|c|c|c|c|c|c|c|c|c|}
\hline & D0 & D2 & D3 & D5 & D6 & D7 & D8 & D9 & D12 & D13 & D15 & D16 & D18 & D19 \\
\hline $\mathrm{K}^{+}(\mathrm{mmol} / \mathrm{L})$ & 1.9 & 2.0 & 3.1 & 2.6 & - & 2.6 & 2.9 & 2.8 & - & - & 3.3 & 3.7 & 3.0 & 2.8 \\
\hline WCC & 4.46 & 2.72 & 3.99 & - & 5.27 & 5.20 & & 4.7 & 5.87 & - & - & 8.38 & 5.41 & - \\
\hline $\mathrm{Hb}(\mathrm{g} / \mathrm{dL})$ & 9.3 & 8.2 & 8.4 & - & 8.2 & 8.0 & & 7.4 & 7.0 & - & - & 8.3 & 7.0 & 6.5 \\
\hline Platelets $\left(\times 10^{9} / \mathrm{L}\right)$ & 170 & 154 & 116 & - & 188 & 203 & & 224 & 113 & - & - & 133 & 14 & 118 \\
\hline $\mathrm{TP}(\mathrm{g} / \mathrm{L})$ & - & - & - & 45 & - & 45 & - & 41 & 37 & 35 & 42 & 44 & 37 & - \\
\hline Albumin $(\mathrm{g} / \mathrm{L})$ & & 21 & & 22 & & 19 & & 21 & 15 & 15 & 18 & 18 & 15 & - \\
\hline AST (IU/L) & - & - & - & 1111 & - & 689 & - & 301 & 3902 & 1157 & 355 & 210 & 93 & 165 \\
\hline
\end{tabular}

Table 3. Liver disease related to pregnancy ${ }^{[8]}$

\begin{tabular}{|c|c|c|c|}
\hline Hyperemesis gravidarum & $\begin{array}{l}\text { Intrahepatic cholestasis of } \\
\text { pregnancy }\end{array}$ & Pre-eclampsia or eclampsia & HELLP syndrome \\
\hline $\begin{array}{l}\text { - In first trimester } \\
\text { - Excessive vomiting } \\
\text { - Dehydration } \\
\text { - Ketosis } \\
\text { - Raised transaminases } \\
\text { - Resolves by } 20 \text { weeks } \\
\text { - Liver abnormality resolves when } \\
\text { vomiting stops } \\
\text { - Needs supportive management }\end{array}$ & $\begin{array}{l}\text { - In second and third } \\
\text { trimesters } \\
\text { - Pruritus of palms and soles } \\
\text { - Raised bile acids } \\
\text { - Resolves with delivery } \\
\text { - Jaundice in }<25 \% \text { of patients } \\
\text { - Treated with UCDA }\end{array}$ & $\begin{array}{l}\text { - Raised systolic blood pressure }>140 \\
\mathrm{mmHg} \text { or diastolic blood pressure } \\
>90 \mathrm{mmHg} \text { occurring after } 20 \text { weeks } \\
\text { - Hepatomegaly/ hepatocellular damage } \\
\text { as part of liver dysfunction } \\
\text { - Epigastric tenderness or RUQ } \\
\text { abdominal pain } \\
\text { - Delivery is the definitive treatment, } \\
\text { from } 34 \text { - } 37 \text { weeks }\end{array}$ & $\begin{array}{l}\text { - Presents between } 28 \text { and } 36 \text { weeks } \\
\text { - Haemolytic anaemia } \\
\text { - Raised transaminases } \\
\text { - Low platelets } \\
\text { - Raised LDH } \\
\text { - Nausea/vomiting } \\
\text { - RUQ or epigastric pain, malaise } \\
\text { - Delivery is the definitive } \\
\text { treatment } \\
\text { - Resolves within } 48 \text { hours of } \\
\text { delivery }\end{array}$ \\
\hline
\end{tabular}


for liver disease to diagnose AFLP. Developed in an obstetric unit in the City of Swansea in southern Wales in 1999 during a study of liver dysfunction in pregnancy, it has since been the standard for diagnosing AFLP with a positive predictive value of $85 \%$ and a negative predictive value of $100 \% \cdot{ }^{[7,8]}$ There are often prodromal symptoms of vomiting, abdominal pain, polydipsia and encephalopathy. ${ }^{[6]}$

The pathophysiology of AFLP is thought to involve fetal deficiency of long-chain hydroxyacyl-CoA dehydrogenase (LCHAD). This is an enzyme involved in long-chain fatty acid metabolism. A deficiency leads to an accumulation of fetal and placental unmetabolised longchain fatty acids in the maternal circulation, causing hepatotoxicity. The differential diagnoses for AFLP are varied, and must be considered. These can be determined by means of biochemical, serological and clinical parameters. Any pregnant woman with abnormal liver functions should undergo the same work-up as for non-pregnant women, as there may be a need for immediate intervention in order to preserve maternal and neonatal health. The liver dysfunction may be pre-existing and coincidental, not relating to pregnancy, such as biliary tract disease (for example, cholecystitis, cholangitis, cholelithiasis), liver masses and viral disease (such as hepatitis A, B, C or E) or may be related to pregnancy (Table 3). ${ }^{[8]}$

Imaging is a useful adjunct in ruling out other liver pathologies, such as biliary tract disease and liver masses. The 'bright liver' often reported in AFLP on ultrasound can also be found in other conditions of liver dysfunction, such as HELLP syndrome. ${ }^{[6,8]}$ Magnetic resonance imaging has been shown to be useful in distinguishing other conditions such as HELLP syndrome from AFLP, and is safe to use in the second and third trimesters of pregnancy. ${ }^{[8,9]}$ AFLP is a microscopic disease. $^{[6]}$

Acknowledgements. Acknowledgements to Dr CN Mnyani and Dr R Wadee for availing us with their time, and for their input in ensuring the completion of this report.

Author contributions. Main text and tables by OUO and CNM. Editing and revision of manuscript, as well as microscopic descriptions, heading and labelling of photomicrograph by RW. Photomicrograph by RW and NN.

Funding. None.

Conflicts of interest. None.

1. Cunningham FG, Leveno KJ, Bloom SL. Williams Obstetrics. 24th ed. New York: McGraw Hill, 2014 2. Ko HH, Yoshida E. Acute fatty liver of pregnancy. Can J Gastroenterol 2006;20(1):25-30. https//doi. org/10.1155/2006/63131

3. Papafragkakis H, Singhal S, Anand S. Acute fatty liver of pregnancy. South Med J 2013;6(10):588593. https://doi.org/10.1097/SMJ.0000000000000007

4. Dwivedi S, Runmei M. A retrospective study of seven cases of acute fatty liver of pregnancy. Obstet Gynecol 2013:730569. https://doi.org/10.1155/2013/730569

5. Nelson DB, Yost NP, Cunningham FG. Acute fatty liver of pregnancy: Clinical outcomes and expected duration of recovery. Am J Obstet Gynecol 2013;209(5):456e1-7. https://doi.org/10.1016/j. ajog.2013.07.006

6. Knight M, Nelson-Piercy C, Kurinczuk JJ, Spark P, Brocklehurst P. A prospective national study of acute fatty liver of pregnancy in the UK. Gut 2008;57(7):951-956. https://doi.org/10.1136/ gut.2008.148676

7. Ching CL, Morgan M, Hainsworth I, Kingham JGC. Prospective study of liver dysfunction in pregnancy in southwest Wales. Gut 2002;51(6):876-880

8. Tran TT, Ahn J, Reau NS. ACG clinical guideline: Liver disease and pregnancy. Am J Gastroenterol 2016;111(2):176-194. https://doi.org/10.1038/ajg.2015.430

9. Chatel P, Ronot M, Roux O, et al. Transient excess of liver fat detected by magnetic resonance imaging in women with acute fatty liver of pregnancy. Am J Obstet Gynecol 2016;214(1):127-129. https://doi.org/10.1016/j.ajog.2015.09.067

Accepted 25 September 2018 